\title{
Selective Separation and Preconcentration of Thorium(IV) in Bastnaesite Ore Using Thorium(IV)-Imprinted Cryogel Polymer
}

\author{
Toryum(IV) Baskılı Kriyojel Polimer Kullanılarak Bastnaesit \\ Cevherindeki Toryum(IV)'un Seçici Olarak Ayrılması ve \\ Önderiştirilmesi
}

Research Article

Ibrahim Dolak

Vocational School of Technical Sciences, Dicle University, Diyarbakır, Turkey.

\section{A B S TR AC T}

\begin{abstract}
I this study, selective separation and preconcentration of Th(IV) in aqueous solutions and bastnaesite ore in the presence various lanthanide ions by using Th(IV)-imprinted polymer was conducted. For this purpose, Th(IV) was complexed with N-methacryloyl antipyrine (MAAP) and the prepared (MAAP)2-Th(IV) complex monomer was polymerized with 2-hydroxyethyl methacrylate (HEMA) cryogel to prepare pHEMA-(MAAP)2Th(IV) cryogel polymer by free radical polymerization. Th(IV) was desorbed with 5.0 mol.L $L^{-1}$ HNO3 and thus Th(IV)-imrinted were created onto p-HEMA-(MAAP)2 cryogel polymer. To determine the optimum conditions, in the process of selective binding of Th(IV) ion to Th(IV)-imprinted p-HEMA-(MAAP) 2 cryogel polymer, some parameters such as $\mathrm{pH}$, flow rate, initial Th(IV) concentration were investigated. Under the optimum conditions, the maximum binding capacity was obtained as $48.30 \mathrm{mg} . \mathrm{g}^{-1}$. Selectivity studies were also carried out in the presence of $\mathrm{Ce}(\mathrm{III}), \mathrm{La}(\mathrm{III})$ and Eu(III) ions using Th(IV)-imprinted p-HEMA-(MAAP) 2 cryogel polymer. It was found that p-HEMA-(MAAP)2 cryogel polymer displayed high selectivity toward Th(IV) ion.
\end{abstract}

\section{Key Words}

Th(IV)-imprinted polymer, p-HEMA-(MAAP)2, separation, preconcentration.

\section{öz}

u çalışmada, Th(IV)-baskılı Polimerler kullanılarak çeşitli lantanid iyonlarının varlığında sulu çözeltilerde ve bastnaesit cevherinde Th(IV) iyonunun seçici olarak ayrılması ve önderiştirilmesi gerçekleştirildi. Bu amaçla, Th(IV), N-metakriloil antipirin (MAAP) ile kompleksleştirildi ve hazırlanan (MAAP)2-Th(IV) kompleks monomer, serbest radikal polimerizasyon yöntemiyle 2-hidroksietil metakrilat (HEMA) kriyojel ile etkileştirilerek pHEMA-(MAAP)2-Th(IV) kriyojel polimeri hazırlandı. Th(IV), $5.0 \mathrm{~mol}^{-L^{-1}} \mathrm{HNO} 3$ ile desorbe edildi ve böylece Th(IV) baskılı p-HEMA-(MAAP)2 kriyojel polimeri oluşturuldu. Th(IV) iyonunun Th(IV)-baskılı p-HEMA-(MAAP)2 kriyojel polimere seçici olarak bağlanması işleminde optimum koşulları belirlemek için pH, akış hızı, başlangıç Th(IV) konsantrasyonu gibi bazı parametreler araştırıldı. Belirlenen bu optimum koşullar altında, maksimum bağlanma kapasitesi 48.30 mg.g-1 olarak tespit edildi. Seçicilik çalışmaları da, Th(IV)-baskılı p-HEMA-(MAAP)2 kriyojel polimer kullanılarak Ce(III), La(III) and Eu(III) iyonlarının varlığında gerçekleştirildi. p-HEMA-(MAAP)2 kriyojel polimer, Th(IV) iyonuna karşı yüksek seçicilik gösterdiği bulundu.

\section{Anahtar Kelimeler}

Th(IV)-baskılı polimer, p-HEMA-(MAAP)2, ayırma, önderiştirme.

Article History: Received: Nov 17, 2017; Revised: Jan 23, 2018; Accepted: Mar 03, 2018; Available Online: Mar 26, 2018

Dol: 10.15671/HJBC.2018.228

Correspondence to: İ. Dolak, Vocational School of Technical Sciences, Dicle University, Diyarbakır, Turkey. 


\section{INTRODUCTION}

Thori horium is a potential nuclear fuel since ${ }^{232} \mathrm{Th}$ can convert to ${ }^{233} \mathrm{Th}$ by absorbing slow neutrons [1]. Thorium is one of rare earth elements which are widely used for the preparation of advanced materials $[2,3]$. Thorium can exist in several rare earth ore samples such as bastnaesite and monazite. Therefore, selective extraction of thorium have attracted significant attention to eliminate radioactive pollution [4]. For this purpose, various techniques such as liquid-liquid extraction $[5,6]$ extraction chromatography $[7,8]$, functionalized resins $[9,10]$, different adsorbents [11,12] and ion imprinted polymers [13-17] have been applied for the selective extraction of thorium and other rare earth ions.

Molecular imprinting is a new technique has attracted the attention of researchers for effective recognation of chemical and biological molecules including aminoacids, proteins, enzymes, DNA, drugs and metals [18-22]. This technique allows selective and sensitive recognition of chosen target molecule by leaving artificial imprinted cavities in polymer matrix that provides high affinity to target molecule [23]. To synthesize molecularly imprinted polymer, the template molecule and functional monomers which can arrange around template are complexed interactively before polymerization. Then the rigid polymer matrix is obtained by polymerization of formed pre-complex and cross-linker reagent. After removal of template molecule from the polymer with suitable elution agent, the cavities remaining in the polymer that are complementary in shape, size and chemical functionality to the template. Consequently, the resultant polymer able to recognizes and rebinds selectively the template or other molecules that are chemically related to the template $[24,25]$. This technique is used in many applications such as selectivity recognation and seperation [26-29], drug delivery systems [30-31], catalysis [32,33] sensor technology [34,35]. In addition, ion imprinted polymers (IIPs) have been used for the selective removal of metal ions from different matrices [36-47].

In this study, the selective separation of Th(IV) in aqueous solutions and bastnaesite ore in the presence of other lanthanide ions such as $\mathrm{La}(\mathrm{III})$, $\mathrm{Ce}(\mathrm{III})$ and $\mathrm{Eu}(\mathrm{III})$ was performed by using Th(IV)- imprinted pHEMA-(MAAP) ${ }_{2}$-Th(IV) cryogel polymer. For this purpose, Th(IV) was complexed with $\mathrm{N}$-methacryloyl antipyrine (MAAP) and the prepared (MAAP) $)_{2}$-Th(IV) complex monomer was polymerized with 2- hydroxyethyl methacrylate (HEMA) cryogel to prepare pHEMA-(MAAP) ${ }_{2}$-Th(IV) cryogel polymer by free radical polymerization. Th(IV) was desorbed

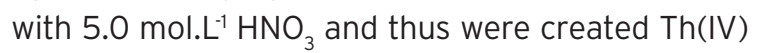
imprinted on to p-HEMA-(MAAP) ${ }_{2}$ cryogel polymer. In the process of selective binding of Th(IV) ion to Th(IV)-imprinted p-HEMA-(MAAP) ${ }_{2}$ cryogel polymer, several factors such as medium $\mathrm{pH}$, flow rate, initial Th(IV) concentration were investigated to determine optimum conditions. Selectivity studies were also carried out in the presence of $\mathrm{Ce}$ (III), La(III) and $\mathrm{Eu}(\mathrm{III})$ ions using Th(IV)-imprinted p-HEMA-(MAAP) cryogel polymer. It was found that $\mathrm{p}$-HEMA-(MAAP) cryogel polymer displayed high selectivity toward Th(IV) ion.

\section{MATERIALS and METHODS}

\section{Chemicals and Reagents}

Metacryloylcloride, antipyrine, thorium(IV) nitrate tetrahydrate, Lanthanium(III) nitrate hexahydrate, Cerium(III) nitrate hexahydrate, Europium(III) nitrate hexahydrate, 2-Hydroxyethyl methacrylate (HEMA), Ammonium persulfate (APS) (MW: 27000), N,N,N,N-tetramethylethylenediamine (TEMED), N,N-methylenebisacrylamide (MBAAm), Polyvinyl alcohol (PVA) and all organic solvents were provided from Sigma-Aldrich (Steinheim, Germany).

\section{Instrumentation}

A Perkin Elmer model Spectrum 400 FT-IR spectrometer was used for the Fourier transform infrared (FT-IR) measurements. Scanning electron microscopy (SEM) analyses were carried out by using a FEI Quanta FEG 250 SEM system. The analysis of the Th(IV) and the other lanthanide ions was performed using a Agilent 7700 Series inductively coupled plasma-mass spectroscopy (ICP-MS). System with the following parameters: RF Power $=1600 \mathrm{~W}$, sampling depth $=5.5 \mathrm{~mm}$, analyzer pressure $=8,31 \times 10^{-5} \mathrm{~Pa}$, helium flow in the collision cell $=5.00 \mathrm{~mL} \cdot \mathrm{min}^{-1}$ and plasma temperature $=9871 \mathrm{~K}$. the measurements were done with three replicates ( $95 \%$ confidence level). 


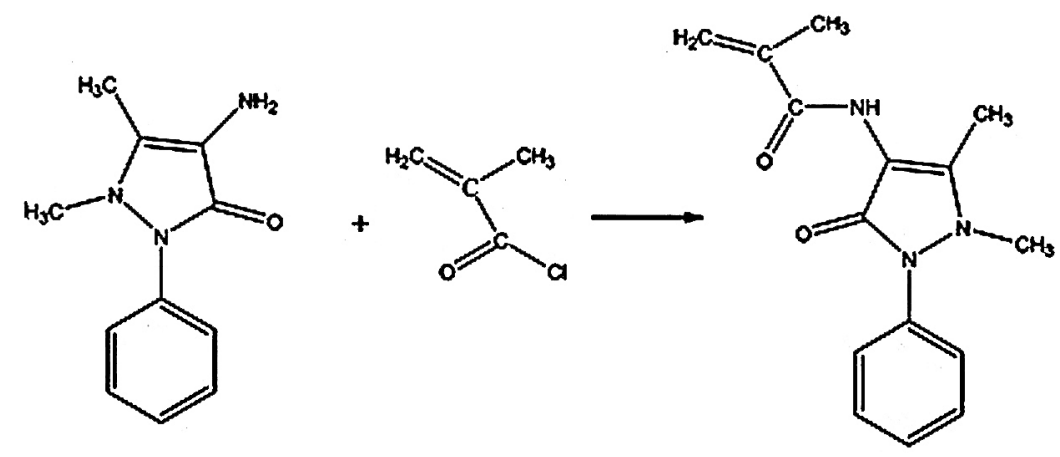

4-Amino Antipyrine Meth cryloyl Chloride Methacryloyl Antipyrine (MAAP)

Figure 1. Synthesis of methacryloyl antipyrine (MAAP) monomer.

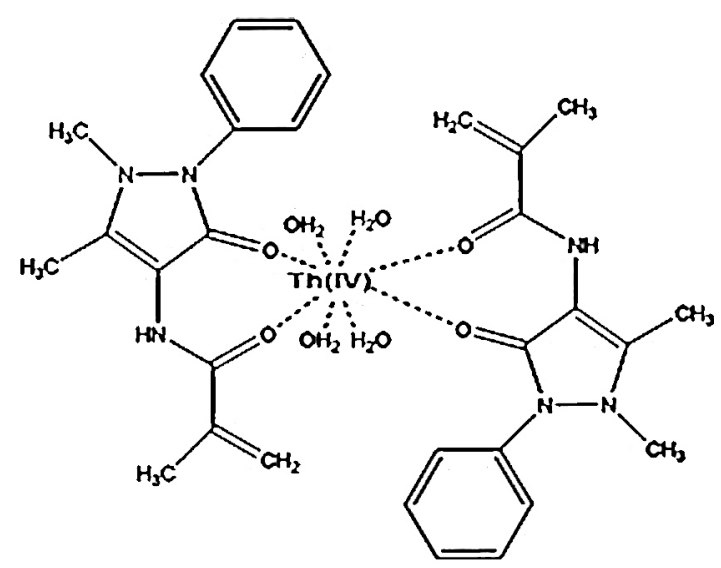

(MAAP) 2 Th(IV) complex monomer

Figure 2. The Prepared (MAAP) 2 Th(IV) complex monomer.

\section{Preparation of Thorium(IV) Imprinted Cryogel}

\section{Polymer Synthesis of Functional Monomer $\mathrm{N}$-Methacryloylamidoantipyrine (MAAP)}

The synthesis of the functional monomer MAAP was carried out apply in the previously reported recipe (Figure 1) [48].

\section{Preparation of (MAAP) ${ }_{2}$-Th(IV) Complex Monomer}

For preparation (MAAP) $)_{2}$-Th(IV) functional monomer (Figure 2), MAAP $(0.270 \mathrm{mg}, 1.0 \mathrm{mmol})$ was dissolved in ethanol. After slow addition of $\mathrm{Th}\left(\mathrm{NO}_{3}\right)_{4} \cdot 4 \mathrm{H}_{2} \mathrm{O}(0.240 \mathrm{mg}, 0.5 \mathrm{mmol})$ to this solution, the solution was stirred for 1 day at room temperature. The obtained complex monomer was then filtered and extensive washed with $\mathrm{EtOH}$ and deionized $\mathrm{H}_{2} \mathrm{O}$. Then, it was dried at $50^{\circ} \mathrm{C}$ for $24 \mathrm{~h}$.

\section{Synthesis p-HEMA-(MAAP) ${ }_{2}-\mathrm{Th}($ IV) Cryogel Polymer (IIP)}

p-HEMA-(MAAP) $)_{2}^{-T h(I V) ~ c r y o g e l ~ p o l y m e r ~ w a s ~}$ prepared according to a previously reported method(Figure 3) [49]. For this purpose, $0.25 \mathrm{~g}$ MBAAm was dissolved in deionized $\mathrm{H}_{2} \mathrm{O}$, and then $1.5 \mathrm{~mL}$ HEMA and $1.5 \mathrm{~mL}$ (MAAP) ${ }_{2}$ Th(IV) complex monomer were mixed with this solution. Initiator APS $(20 \mathrm{mg}) /$ TEMED $(20 \mu \mathrm{l})$ was added and the final mixture was placed into a syringe closed with parafilm and allowed to polymerize at -18 ${ }^{\circ} \mathrm{C}$ for $24 \mathrm{~h}$. The frozen solution was allowed to thaw at room temperature. Finally, the prepared imprinted cryogel polymer was washed with $\mathrm{EtOH}$ and deionized $\mathrm{H}_{2} \mathrm{O}$ to remove impurities, which was then stored at $+4^{\circ} \mathrm{C}$. 


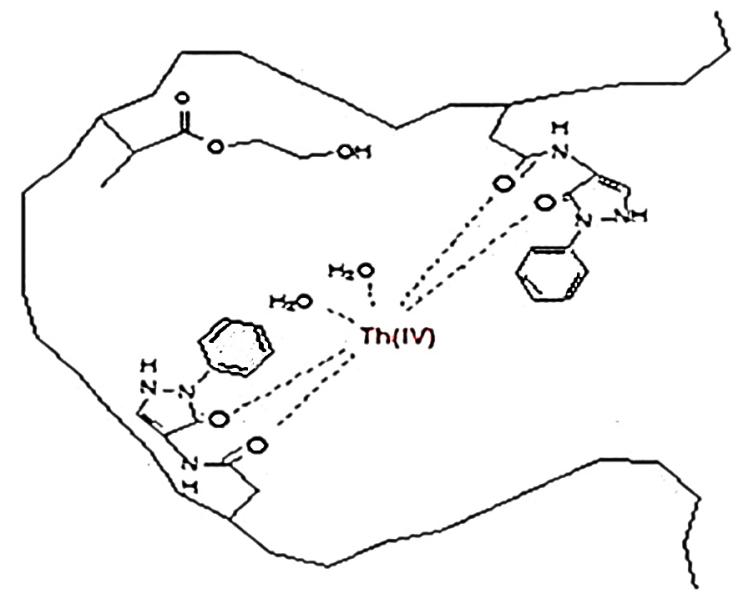

Th(IV)-imprinted p-HEMA-(MAAP) 2 Th(IV) Cryogel polymeI

Figure 3. Schematic depiction of the prepared Th(IV)-imprinted p-HEMA-(MAAP) ${ }_{2}$ Th(IV) Cryogel polymer.

\section{Removal of Th(IV) from $p$-HEMA-(MAAP) ${ }_{2}^{-}$ Th(IV) Cryogel Polymer (IIP)}

To obtain the 3-D cavities for re-binding of Th(IV), the template Th(IV) was successfully desorbed from the $\mathrm{p}$-HEMA-(MAAP) ${ }_{2}$-Th(IV) cryogel polymer. For this purpose, the cryogel polymer was desorbed with 5.0 mol.L-1 $\mathrm{HNO}_{3}$ as the desorbtion solvent for $1 \mathrm{~h}$ by using a peristaltic pump. This washing step was repeated until no Th(IV) was determined in the desorption solvent.

\section{Characterization Studies}

MAAP monomer and Prepared (MAAP) ${ }_{2}$-Th(IV) complex monomer were characterized by FTIR spectroscopy, whereas p-HEMA-(MAAP) cryogel polymer were characterized by and SEM technique. To obtain FT-IR spectra p-HEMA$(\mathrm{MAAP})_{2}$ cryogel polymer, $\mathrm{KBr}$ was mixed with the dried polymer particles and pressed into a pellet form, and the spectra were then recorded.

For the SEM analysis of p-HEMA-(MAAP) $)_{2}$ cryogel polymer were covered on the surface of platinum and coated with gold (thicknes of $20 \mathrm{~nm}$ ). Then, SEM analyses were carried out.

To calculate the swelling ratio of $p$-HEMA$\left(\right.$ MAAP) ${ }_{2}$ cryogel polymer, the cryogel was dried and weighed until constant weight $\left(\mathrm{m}_{\text {dried }}\right)$. Then, it was placed in a $30 \mathrm{~mL}$ vial containing distilled water and kept at $25^{\circ} \mathrm{C}$ for $2 \mathrm{~h}$. The cryogel was removed from water, wiped by a filter paper and weighed again $\left(m_{\text {wet }}\right)$. The swelling ratio was calculated according to;

$\mathrm{S}=\mathrm{m}_{\text {wet }}-\mathrm{m}_{\text {dried }} / \mathrm{m}_{\text {dried }}$
For the measurement of macroporosity percentage $(\mathrm{M} \%)$ of cryogels, the mass of watersaturated cryogels $\left(m_{\text {wet }}\right)$ was weighed. The cryogel was squeezed to remove free water which is found in the pores (msqueezed), and the mass of cryogel without water was weighted. M\% was calculated according to;

$\mathrm{M} \%=\mathrm{m}_{\text {wet }}-\mathrm{m}_{\text {squeezed }} / \mathrm{m}_{\text {wet }}$

\section{Binding Studies of Th(IV) lon to IIP and NIP}

Continuous column system was used to bind Th(IV) to Th(IV)-imprinted p-HEMA-(MAAP) cryogel polymer (IIP) and non-imprinted p-HEMA(MAAP) $_{2}$ cryogel polymer (NIP). For this purpose, firstly, columns containing IIP and NIP was washed with deinozed $\mathrm{H}_{2} \mathrm{O}$ and equilibrated with $0.1 \mathrm{~mol}^{\mathrm{L}} \mathrm{L}^{-1}$ phosphate buffer, $\mathrm{pH}$. 7.0. Then, aqueous solution of Th(IV) was passed through the columns containing IIP and NIP at $1 \mathrm{~mL} \cdot \mathrm{min}^{-1}$ flow rate for $1 \mathrm{~h}$. The amounts of Th(IV) was determined by ICP-MS. Then, 5.0 mol.L-1 $\mathrm{HNO}_{3}$ was used to desorption Th(IV) bound to the IIP and NIP. Sevaral factors such as $\mathrm{pH}$, flow rate and initial Th(IV) concentration were also investigated to obtain the optimum conditions for the binding of Th(IV) to the IIP and NIP. 10 $\mathrm{ppm} \mathrm{Th}(\mathrm{IV})$ in different $\mathrm{pH}$ values ( $\mathrm{pH} 3$ to 10) was passed through the columns containing IIP and NIP at $1 \mathrm{~mL} \cdot \mathrm{min}^{-1}$ flow rate for $1 \mathrm{~h}$ in order to test $\mathrm{pH}$ influence on Th(IV) binding to the IIP and NIP. Then, the samples came out from the column were analyzed by ICP-MS. The flow rates between $1.0 \mathrm{~mL}$. $\mathrm{min}^{-1}$ and $5.0 \mathrm{~mL}$. $\mathrm{min}^{-1}$ were applied for the investigation of the effects of these parameters 
on the binding of Th(IV) to the IIP and NIP. The initial Th(IV) concentration was varied between $10 \mathrm{pmm}$ and $3000 \mathrm{ppm}$ to determine maximum binding capacity.

\section{Selectivity and Reusability of the Prepared IIP and NIP}

The selectivity of the preapred IIP and NIP toward Th(IV) were investigated in the presence of Th(IV)La(III), Th(IV)-Ce(III) and Th(IV)-Eu(III) ion pairs. For this purpose $25 \mathrm{~mL}$ of $10 \mathrm{ppm}$ lanthanide solutions in $10 \mathrm{mM}$ acetate buffer, pH 5.0 were passed from columns containing IIP and NIP at a flow rate of $1 \mathrm{~mL} \cdot \mathrm{min}^{-1}$ at room temperature. Analysis of the lanthanide ions in the column output samples was performed by ICP-MS.

The distribution coefficient of Th(IV) ion between the columns containing IIP-NIP and aqueous solutions was calculated using the following formula:

$K_{d}=\left(C_{i}-C_{f} / C_{i}\right) \times(V / m)$

where $K_{d}$ is the distribution coefficient, $C_{i}$ is initial Th(IV) concentration and $C_{f}$ is final Th(IV) concentration, $V$ represents the solution volume $(\mathrm{mL})$ and $\mathrm{m}$ is the polymer mass $(\mathrm{g})$.

The selectivity coefficient ( $k$ ) and relative selectivity coefficient ( $k^{\prime}$ ) for Th(IV) in the presence of other competing lanthanide ions can be calculated applying the following equation:

$k=K(T h(I V)) / K($ interfering ion)

$\mathrm{K}^{\prime}=\mathrm{K}($ imprinted $) / \mathrm{K}($ nonimprinted $)$

where $K(T h(I V))$ is the distribution ratio of $T h(I V)$ ion and $K$ (interfering ion) is the distribution ratio of potentially interfering ions.

For the reusability studies, binding and leach studies were repeated 10 times using same IIP. After each step, column containing IIP was washed with 5 mol. $\mathrm{L}^{-1} \mathrm{HNO}_{3}$ and deionized water.

\section{Binding Studies of Th(IV) Ion from Bastnaesite Ore}

Bastnaesit ore was selected as the real sample for the selective binding of Th(IV). For this purpose, $1 \mathrm{~g}$ powdered bastnaesite ore was leached using concentrated $\mathrm{HNO}_{3}$ and $\mathrm{H}_{2} \mathrm{SO}_{4}$ by microwave irradiation. Then, solution $\mathrm{pH}$ was adjusted to 5.0 using acetate buffer and volume of the final solution was distilled to $100 \mathrm{~mL}$ by deionized water. The prepared bastnaesite solution was passed through the columns containing IIP and NIP the under the optimum conditions. Analysis of the ions in the column output samples was performed by ICP-MS.

\section{RESULTS and DISCUSSION}

\section{Characterization of MAAP and (MAAP) ${ }_{2}$ Th(IV) Complex Monomer}

Prepared (MAAP) 2 -Th(IV) complex monomer were characterized by FT-IR spectroscopy, which proved that monomer and complex monomer were synthesized. The obtained FT-IR spectrum of the functional monomer MAAP is given in Figure 4. The spectra shows the characteristic bands of monosubstituted benzene ring at $713.6 \mathrm{~cm}^{-1}$ and strong bands at $1412.7 \mathrm{~cm}^{-1}$ indicating conjugation at aromatic ring and $\mathrm{CH} 2$ vibration band. The absorption bands due to amide carbonyl were observed at $1659.5 \mathrm{~cm}^{-1}$. Aromatic and aliphatic $\mathrm{C}-\mathrm{H}$ bands were observed at 3032.5 and 2991.0 $\mathrm{cm}^{-1}$, respectively and $\mathrm{N}-\mathrm{H}$ band at $3209.5 \mathrm{~cm}^{-1}$ confirmed the MAAP structure. In the FT-IR spectrum of complex monomer, the absorption band at $1659.5 \mathrm{~cm}^{-1}$ due to amide carbonyl was shifted to $1662.3 \mathrm{~cm}^{-1}$ due to the interaction between carbonyl bond and Th(IV). The C-N strength band at $1114.7 \mathrm{~cm}^{-1}$ was shifted to 1151.4 $\mathrm{cm}^{-1}$, indicating Th(IV) interaction. Thus, this FT-IR spectrum confirmed synthesis of (MAAP)2-Th(IV) complex monomer.

\section{Characterization of Th(IV)-Imprinted p-HEMA-(MAAP) ${ }_{2}$ Cryogel Polymer (IIP)}

p-HEMA and Th(IV)-imprinted p-HEMA-(MAAP) $)_{2}$ cryogel polymer (IIP) were characterized by FTIR and SEM. Figure 5a shows the FT-IR Spectra p-HEMA and Th(IV)-imprinted p-HEMA-(MAAP) cryogel polymer (IIP). As can be seen, p-HEMA and Th(IV)-imprinted $p$-HEMA-(MAAP), cryogel polymer (IIP) exhibited FT-IR patterns with small differences which confirms the similar polymer backbone. The pore structure and pore size of Th(IV)-imprinted p-HEMA-(MAAP) ${ }_{2}$ cryogel polymer (IIP) were visualized with SEM images as seen in Figure $5 \mathrm{~b}$. As shown in the figure 
$5 b$, the p-HEMA-(MAAP) ${ }_{2}$ cryogel polymer has interconnected pores and porous structure. Pore size was found about $50 \mu \mathrm{m}$. The equilibrium swelling degree and macroporosity of the p-HEMA-(MAAP) ${ }_{2}$ cryogel were $6.74 \mathrm{~g} \mathrm{H}_{2} \mathrm{O} / \mathrm{g}$ cryogel and $77.61 \%$, respectively.

\section{Binding Studies of Th(IV) on IIP and NIP pH effect on Th(IV) Binding}

The change in amount of Th(IV) binding to the IIP and NIP as a function of $\mathrm{pH}$ was investigated, as seen in Figure 6. The maximum Th(IV) binding to the IIP and NIP pH 5.0. This could be explained by electron transfer based covalent cross-linking between Th(IV) and antypirine of the functional monomer at pH $5.0[13,50]$. Figure 6 clearly shows effect of $\mathrm{pH}$ on Th(IV) binding to thellP and NIP. As seen in the figure, the values higher and lower than $\mathrm{pH} 5.0$ lead to low binding of Th(IV) to the IIP and NIP, which can be explained by the repulsive electrostatic interactions between bound Th(IV) ion and antipyrine monomer. The binding efficiency may decrease because of the size of conformation and the lateral electrostatic interactions between adjacent Th(IV) ion on the IIP and NIP.

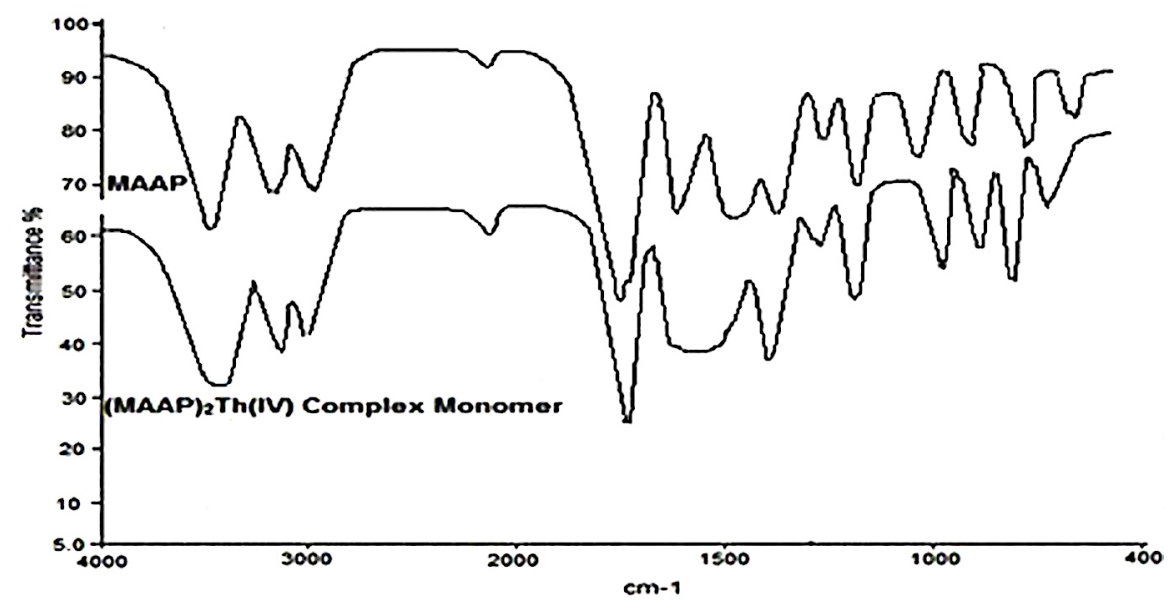

Figure 4. FT-IR spectrum of MAAP and (MAAP) ${ }_{2}$-Th(IV) complex monomer.
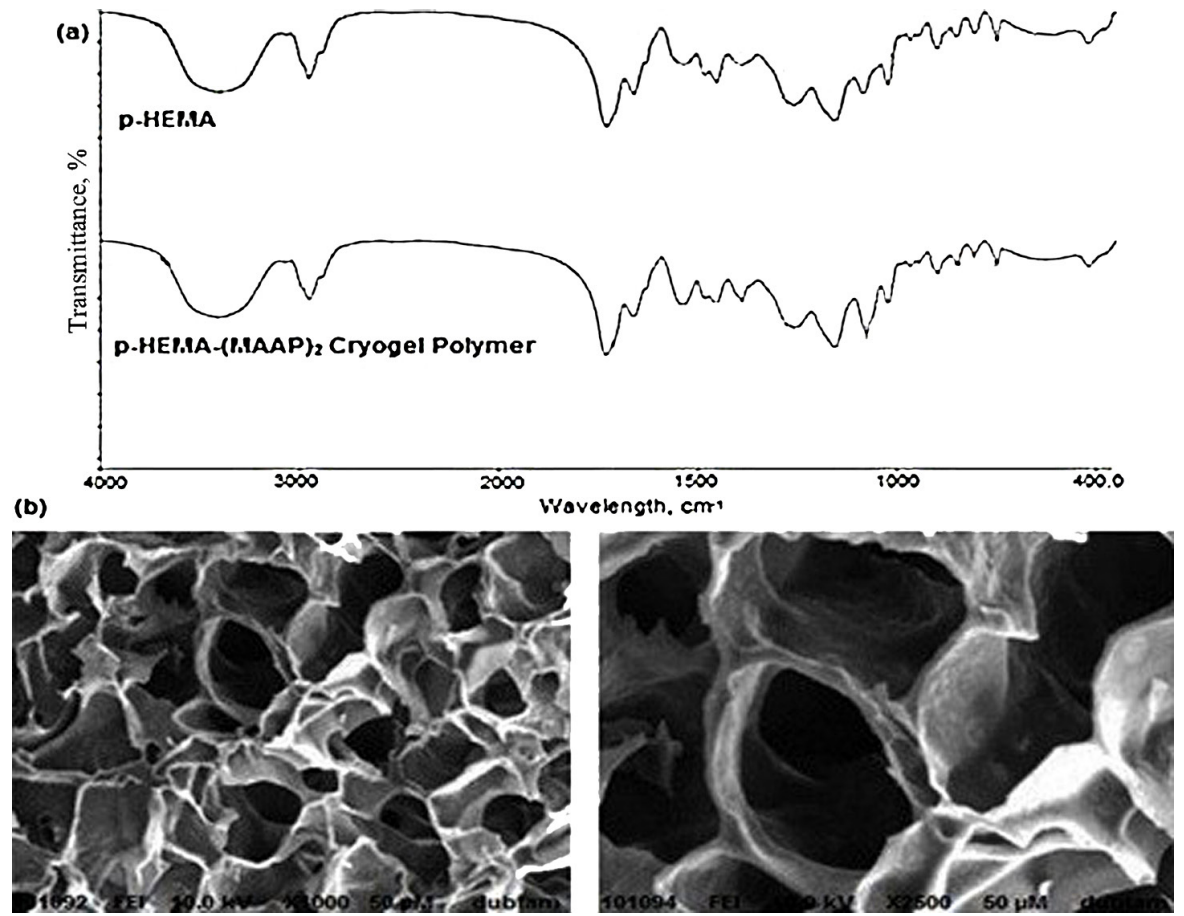

Figure 5. (a) FT-IR Spectra p-HEMA and Th(IV)-imprinted p-HEMA-(MAAP) ${ }_{2}$ (b) SEM images Th(IV)-imprinted p-HEMA$(\mathrm{MAAP})_{2}$ cryogel polymer (IIP). 


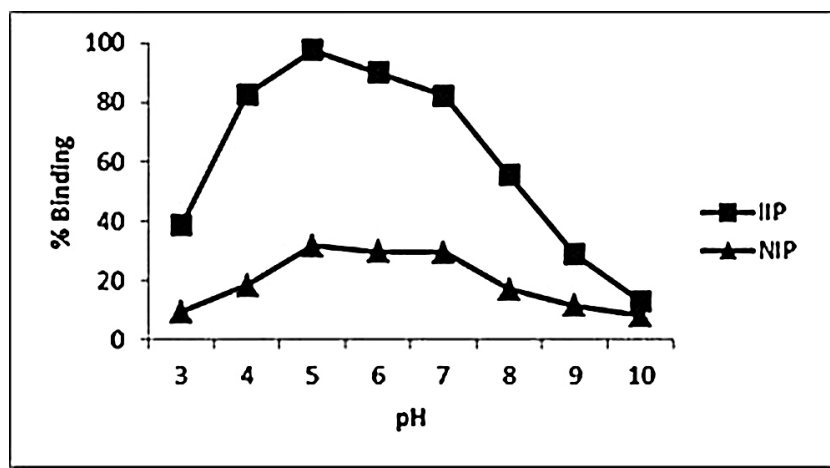

Figure 6. Effect of $\mathrm{pH}$ on Th(IV) Binding. Experimental conditions: Initial Th(IV) Concentration: 10 ppm; Temperature: $25^{\circ} \mathrm{C}$; Flow rate: $1 \mathrm{mLmin}^{-1}$; Time: $1 \mathrm{~h}$.

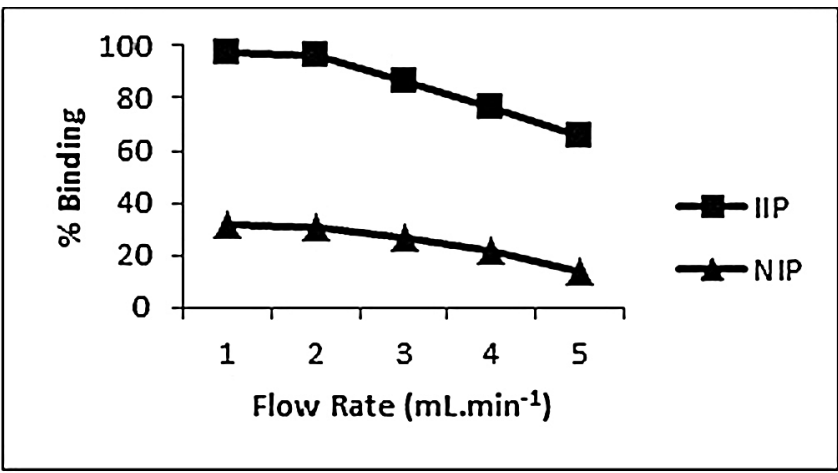

Figure 7. Effect of Flow Rate on Th(IV) Binding. Experimental conditions: $\mathrm{pH}$ : 5; Initial Th(IV) Concentration: $10 \mathrm{mg} . \mathrm{L}^{-1}$, Temperature: $25^{\circ} \mathrm{C}$; Time: $1 \mathrm{~h}$.

\section{Flow Rate Effect on Th(IV) Binding}

The flow rate of the Th(IV) solution pumped through the cryogel is one of the crucial parameter for the control of binding process [51]. The flow rate effect on the binding of Th(IV) was explored by changing the flow rate from 1.0 to $5.0 \mathrm{~mL}$. $\mathrm{min}^{-1}$.

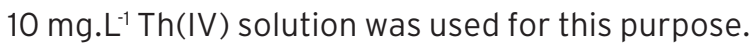
Owing to the back pressure produced by the column, the flow rates higher than $5.0 \mathrm{~mL} \cdot \mathrm{min}^{-1}$ could not be investigated. As shown in Figure 7, increasing flow rate resulted in a decrease in the binding of Th(IV) from $97.52 \%$ to $65.26 \%$ binding capacity.

\section{Initial Th(IV) Concentration Effect on Th(IV) Binding}

Initial Th(IV) concentration dependence of the bound amount of the Th(IV) on to IIP and NIP is depicted in Figure 8. As can be seen, Th(IV) binding increased when initial Th(IV) concentration is increased, and an equilibrium was obtained at a Th(IV) concentration of $3000 \mathrm{ppm}$. The maximum

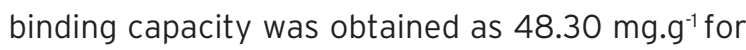
IIP, while that of NIP was $6.72 \mathrm{mg} \mathrm{g}^{-1}$. it was found that maximum binding yield obtained was fairly good result when compared to other studies [1351,52].

\section{Regeneration and Reusability of the Th(IV)- Impirinted pHEMA-(MAAP) ${ }_{2}$ Cryogel Polymer (IIP)}

One of the crucial advantage for an affinity material for the recognition and separation processes is its reusability. To test the reusability of the prepared IIP, Th(IV) binding and elution cycle was repeated 10 times using the same cryogel (Figure 9).

The elution of Th(IV) from the IIP was performed by using $5.0 \mathrm{~mol}^{-1} \mathrm{~L}^{-1} \mathrm{HNO}_{3}$ as the desorption solution and complete removal of Th(IV) was achieved after the desorption step. It was found that the binding behavior of the IIP towards Th(IV) did not changed significantly after ten binding and desorption cycles. Thus, one can easily say that the IIP are stable and the IIP can be used many times without significantly loss of their binding capacity.

\section{Selectivity Studies}

Competitive binding of Th(IV)-La(III), Th(IV)$\mathrm{Ce}(\mathrm{III})$ and Th(IV)-Eu(III) were also explored in a column system. The obtained results are given in Table 1. Th(IV) imprinted cryogel polymer (IIP) exhibited higher selectivity toward Th(IV) ions over $\mathrm{La}(\mathrm{III}), \mathrm{Ce}(\mathrm{III})$ and $\mathrm{Eu}(\mathrm{III})$ ions. Kd values for the IIP were compared with NIP. The obtained 


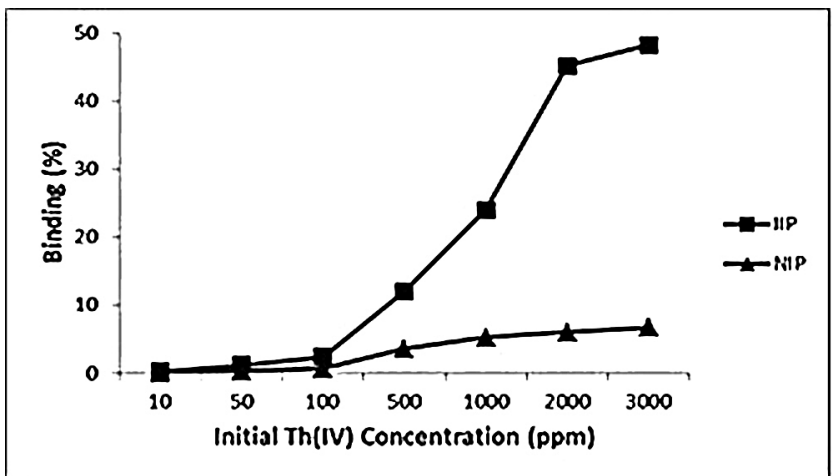

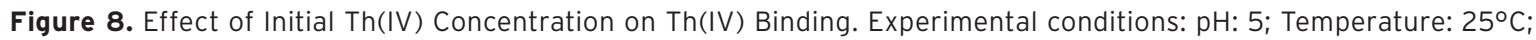
Flow rate: $1 \mathrm{~mL}$. $\mathrm{min}^{-1}$; Time: $1 \mathrm{~h}$.

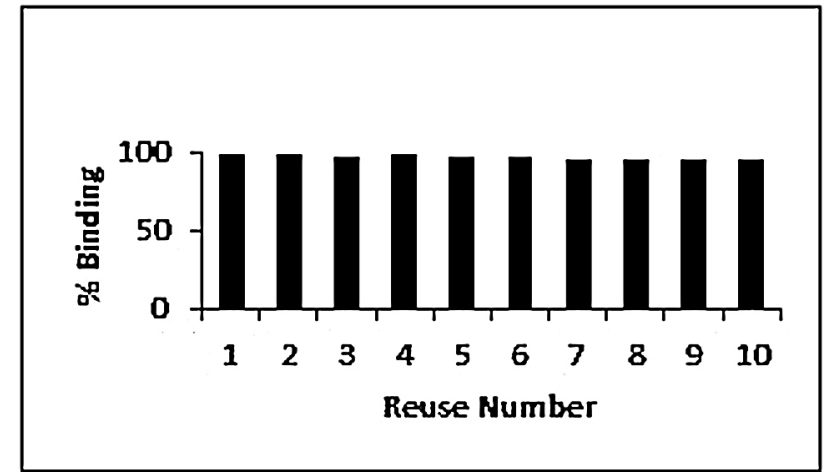

Figure 9. Reusability of IIP. Experimental conditions: $\mathrm{pH}$ : 5; Initial Th(IV) Concentration: $10 \mathrm{mg} \mathrm{L} \mathrm{L}^{-1}$; Temperature: $25^{\circ} \mathrm{C}$; Flow rate: $1 \mathrm{~mL} \cdot \mathrm{min}^{-1}$; Time: $1 \mathrm{~h}$.

Table 1. $\mathrm{K}_{\mathrm{d}^{\prime}} \mathrm{k}$ and $\mathrm{k}^{\prime}$ values of $\mathrm{La}(\mathrm{III}), \mathrm{Ce}(\mathrm{III})$ and $\mathrm{Eu}(\mathrm{III})$ with respect to Th(IV). Experimental conditions: $\mathrm{pH}$ : 5; Temperature: $25^{\circ} \mathrm{C}$; Flow rate: $1 \mathrm{~mL}$. min ${ }^{-1}$; Time: $1 \mathrm{~h}$.

\begin{tabular}{|c|c|c|c|c|c|c|}
\hline Cryogel Column & $\operatorname{Th}(\mathrm{IV})(\mathrm{mg} / \mathrm{L})$ & $\mathrm{La}(\mathrm{III})(\mathrm{mg} / \mathrm{L})$ & $\mathrm{Kd}(\mathrm{Th}(\mathrm{IV}))$ & $\mathrm{Kd}(\mathrm{La}(\mathrm{III}))$ & k & $k^{\prime}$ \\
\hline Non-imprinted & 10 & 10 & 467.8 & 2874.4 & 0.16 & - \\
\hline Th(IV)-imprinted & 10 & 10 & 11206 & 863.5 & 12.3 & 77 \\
\hline Cryogel Column & $\operatorname{Th}(\mathrm{IV})(\mathrm{mg} / \mathrm{L})$ & $\mathrm{Ce}(\mathrm{III})(\mathrm{mg} / \mathrm{L})$ & $\mathrm{Kd}(\operatorname{Th}(\mathrm{IV}))$ & $\mathrm{Kd}(\mathrm{Ce}(\mathrm{III}))$ & k & $k^{\prime}$ \\
\hline Non-imprinted & 10 & 10 & 1095.4 & 3026.0 & 0.36 & - \\
\hline Th(IV)-imprinted & 10 & 10 & 97335 & 2492.5 & 39 & 108 \\
\hline Cryogel Column & $\operatorname{Th}(\mathrm{IV})(\mathrm{mg} / \mathrm{L})$ & $\mathrm{Eu}(\mathrm{III})(\mathrm{mg} / \mathrm{L})$ & $\mathrm{Kd}(\mathrm{Th}(\mathrm{IV}))$ & $\mathrm{Kd}(\mathrm{Eu}(\mathrm{III}))$ & k & $k^{\prime}$ \\
\hline Non-imprinted & 10 & 10 & 530.7 & 1978.5 & 0.27 & - \\
\hline Th(IV)-imprinted & 10 & 10 & 66764 & 2578.6 & 26 & 96 \\
\hline
\end{tabular}




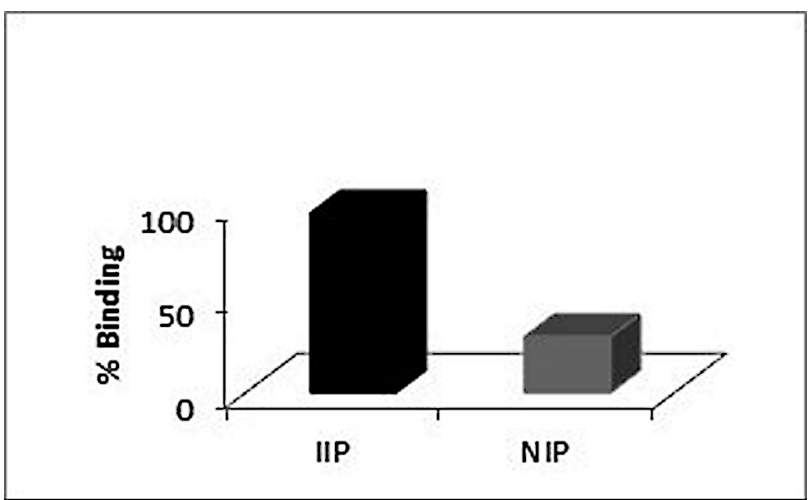

Figure 10. Selective Separation of Th(IV) from Bastnaesite Ore. Experimental Conditions: $C_{\text {Th(IV) }}=2.65 \mathrm{mg} \cdot \mathrm{L}^{-1}$ (in the real sample), $\mathrm{pH}=5.0$, Flow Rate $=1 \mathrm{~mL} \cdot \mathrm{min}^{-1}, \mathrm{~T}=25^{\circ} \mathrm{C}$.

results confirmed that the relative selectivity coefficients of the IIP for the Th(IV)/La(III), Th(IV)/ $\mathrm{Ce}(\mathrm{III})$ and Th(IV)/Eu(III) were 77, 108 and 96 times higher than the corresponding NIP, respectively. As a result, it was found that the prepared Th(IV)imprinted cryogel polymer exhibited a high selectivity to $\mathrm{Th}(\mathrm{IV})$ ion in the presence of other lanthanides [13].

\section{Selective Separation of Th(IV) from Basnaesite Ore}

The outcomes of the binding experiments of Th(IV) from bastnaesite ore, which provided from Eskişehir-Sivrihisar region are given in Figure 10. The results showed that the IIP displayed $95.88 \%$ binding toward Th(IV) while NIP showed $29.76 \%$ binding.

\section{CONCLUSION}

In this study, a new IIP (p-HEMA-(MAAP) $)_{2}$ ) that shows high affinity and selectivity toward Th(IV) was prepared. The obtained results showed that the prepared IIP selectively binds Th(IV) ions in the presence of other lanthanide ions Eu(III), $\mathrm{Ce}(\mathrm{III})$ and $\mathrm{La}$ (III) from aqueous solutions and bastnaesite ore. Under the optimum conditions, the maximum binding capacity of the prepared IIP was obtained as 48.30 mg.g $\mathrm{g}^{-1}$. Consequently, a separation material has been developed which will contribute to the separation and preconcentration of the Th(IV) by the IIP, specially designed for use in nuclear power plants as an alternative to uranium, from other components with high selectivity.

\section{References}

1. S.F. Ashley, G.T. Parks, W.J. Nuttall, C. Boxall, R.W. Grimes, Thorium fuel has risks, Nature, 492 (2012) 31-33.

2. Y.P. Du, Y.W.Zhang, Z.G. Yan, L.D. Sun, C.H. Yan, Highly luminescent self-organized sub-2-nm EuOF nanowires, J. Am. Chem. Soc., 131 (2009) 16364-16365.

3. B.G. Shen, J.R. Sun, F.X. Hu, H.W. Zhang, Z.H. Cheng, Recent progress in exploring magnetocaloric materials, Adv. Mater., 21 (2009) 4545-4564.

4. V.K. Jain, A. Handa, S.S. Sait, P. Shrivastav, Y.K. Agrawal, Pre-concentration, separation and trace determination of lanthanum(III), cerium(III), thorium(IV) and uranium(VI) on polymer supported o-vanillinsemicarbazone, Anal. Chim. Acta, 429 (2001) 237-246.

5. I. Dolak, M. Karakaplan, B. Ziyadanoğulları, R. Ziyadanoğulları, Solvent extraction, preconcentration and determination of thorium with monoaza 18-Crown- 6 derivative, Bul. Kor. Chem. Soc., 32 (2011) 1564-1568.

6. S.K. Sahu, V. Chakravortty, M.L.P. Reddy, T.R. Ramamohan, The synergistic extraction of thorium(IV) and uranium(VI) with mixtures of 3-phenyl-4-benzoyl-5-isoxazolone and crown ethers, Talanta, 51 (2000) 523-530.

7. Q. He, X. Chang, Q. Wu, X. Huang, Z. Hu, Y. Zhai, Synthesis and applications of surface-grafted Th(IV)-imprinted polymers for selective solid-phase extraction of thorium(IV), Anal. Chim. Acta, 605 (2007) 192-197.

8. C. Lin, H. Wang, Y. Wang, Z. Cheng, Selective solidphase extraction of trace thorium(IV) using surfacegrafted Th(IV)-imprinted polymers with pyrazole derivative, Talanta, 81 (2010) 30-36.

9. Y. Chen, Y. Wei, L. He, F. Tang, Separation of thorium and uranium in nitric acid solution using silica based anion exchange resin, J. Chrom. A, 1466 (2016) 37-41.

10. S. Chandramouleeswaran, J. Ramkumar, n-Benzoyl-nphenylhydroxylamine impregnated Amberlite XAD-4 beads for selective removal of thorium, J. Haz. Mat., 280 (2014) 514-523. 
11. M.A.A. Aslani, F. Celik, S. Yusan, C.R.K. Aslani, Assessment of the adsorption of thorium onto styrene-divinylbenzene-based resin: Optimization using central composite design and thermodynamic parameters, Pro. Saf. Enviro. Pro., 109 (2017) 192-202.

12. F. Khalili, G. Al-Banna, Adsorption of uranium(VI) and thorium(IV) by insolubilized humic acid from Ajloun soil e Jordan, J. Enviro. Radio., 146 (2015) 16-26.

13. S. Buyuktiryaki, R. Say, A. Ersoz, E. Birlik, A. Denizli, Selective preconcentration of thorium in the presence of $\mathrm{UO}_{2}{ }^{2+}, \mathrm{Ce}^{3+}$ and $\mathrm{La}^{3+}$ using Th(IV)-imprinted polymer, Talanta, 67 (2005) 640-645.

14. N. Bereli, D. Türkmen, K. Köse, A. Denizli, Glutamic acid containing supermacroporous poly(hydroxyethyl methacrylate) cryogel disks for $\mathrm{UO}_{2}{ }^{2+}$ removal, Mat. Sci. Eng. C, 32 (2012) 2052-2059.

15. M.M. Yusoff, N. Rohani, N. Mostapa, M.S. Sarkar, T.K Biswas, M.L. Rahman, S.E. Arshad, M.S. Sarjadi, A.D. Kulkarni, Synthesis of ion imprinted polymers for selective recognition and separation of rare earth metals, J. Rare Earths, 35 (2017) 177-185.

16. L. Uzun, R. Uzek, S. Senel, R. Say, A. Denizli, Chiral recognition of proteins having L-histidine residues on the surface with lanthanide ion complex incorporatedmolecularly imprinted fluorescent nanoparticles, Mat. Sci. Eng. C, 33 (2013) 3432-3439.

17. i. Dolak, R. Keçili, D. Hür, A. Ersöz, R. Say, lon-imprinted polymers for selective recognition of neodymium (III) in environmental samples, Ind. Eng. Chem. Res., 54 (2015) 5328-5335.

18. M. Gedikli, Ş. Ceylan, M. Erzengin, M. Odabaşı, A novel matrix for hydrophobic interaction chromatography and its application in lysozyme adsorption, Acta Biochim. Pol., 61 (2014) 731-737.

19. I. Göktürk, R. Üzek, L. Uzun, A. Denizli, Synthesis of a specific monolithic column with artificial recognition sites for L-glutamic acid via cryo-crosslinking of imprinted nanoparticles, Nanomedicine Biotech., 44 (2016) 1133-1140.

20. M. Odabaşı, G. Baydemir, M. Karatas, A. Derazshamshir Preparation and characterization of metal-chelated poly(HEMA-MAH) monolithic cryogels and their use for DNA adsorption, J. App. Pol. Sci., 116 (2010) 13061312.

21. K. Balamurugan, K. Gokulakrishnan, T. Prakasam, Preparation and evaluation of molecularly imprinted polymer liquid chromatography column for the separation of Cathine enantiomers, Saudi Pharm. J. 20 (2012) 53-61.

22. R. Say, E. Birlik, A. Ersöz, F. Yilmaz, T. Gedikbey, A. Denizli, Preconcentration of copper on ion-selective imprinted polymer microbeads, Anal. Chim. Acta. 480 (2003) 251-258.

23. E. Tamahkar, Adil Denizli, Metal ion coordination interactions for biomolecule recognition: a Review, Hittite J. Sci. and Eng., 2014, 121-26.

24. Y. Saylan, F. Yilmaz, E. Özgür, A. Derazshamshir, H. Yavuz, A. Denizli, Molecular imprinting of macromolecules for sensor applications, Sensors, 17 (2017) 1-30.
25. G. Vasapollo, R.D. Sole, L. Mergola, M.R. Lazzoi, A. Scardino, S. Scorrano, G. Mele, Molecularly imprinted polymers: Present and future prospective, Int. J. Mol. Sci. 12 (2011) 5908-5945.

26. H.J. Monodispersed, molecularly imprinted polymers as affinity-based chromatography media, J. Chrom. B, 866 (2008) 3-13.

27. S. Wei, B. Mizaikoff, Recent advances on noncovalent molecular imprints for affinity separations, J. Sep. Sci., 30 (2007) 1794-1805.

28. M. Lasáková, P. Jandera, Molecularly imprinted polymers and their application in solid phase extraction, J. Sep. Sci., 32 (2009) 788-812

29. B. Sellergren, Imprinted chiral stationary phases in high-performance liquid chromatography, J. Chrom. A, 906 (2001) 227-252.

30. F. Puoci, F. Lemma, N. Picci, Stimuli-responsive molecularly imprinted polymers for drug delivery: A review, Curr. Drug Deliv., 5 (2008) 85-96.

31. A. Concheiro, Molecularly imprinted polymers for drug delivery, J Chrom. B, 804 (2004) 231-45.

32. G. Wulff, Enzyme-like catalysis by molecularly imprinted polymers, Chem. Rev., 102 (2002) 1-27.

33. S. Vidyasankar, F.H. Arnold, Molecular imprinting: Selective materials for separations, sensors and catalysis, Curr. Opin. Biotech., 6 (1995) 218-224.

34. G. Selvolini, G. Marrazza, MIP-Based Sensors: Promising New Tools for Cancer Biomarker Determination, Sensors, 17 (2017) 718-736.

35. B.D. Gupta, A.M. Shrivastav, S.P. Usha, Surface plasmon resonance-based fiber optic sensors utilizing molecular imprinting, Sensors, 16 (2016) 1381-1413.

36. S.M. Madhappan, K.T. Pradip, S.P. Sung, M. Aneesh, J.C. Hun, S.H. Chang, On-imprinted mesoporous silica hybrids for selective recognition of target metal ions, Micropor. Mesopor. Mat., 180 (2013) 162-171.

37. M. Monier, D.A. Abdel-Latif, Fabrication of Au(III) ionimprinted polymer based on thiol-modified chitosan, Int. J. Bio. Macro., 105 (2017) 777-787.

38. R. Msaadi, S. Ammar, M.M. Chehimi, Y. Yagci, Diazonium-based ion-imprinted polymer/clay nanocomposite for the selective extraction of lead(II) ions in aqueous media, Eur. Pol. J., 89 (2017) 367-380.

39. M. Monier, D.A. Abdel-Latif, Y.G. Abou El-Reash, Ion-imprinted modified chitosan resin for selective removal of Pd(II) ions, J. Col. Inter. Sci., 469 (2016) 344-354.

40. M. Roushani, S. Abbasi, H. Khani, R. Sahraei, Synthesis and application of ion-imprinted polymer nanoparticles for the extraction and preconcentration of zinc ions, Food Chem., 173 (2015) 266-273.

41. M. Mitreva, I. Dakova, I. Karadjova, Iron(II) ion imprinted polymer for $\mathrm{Fe}(\mathrm{II}) / \mathrm{Fe}(\mathrm{III})$ speciation in wine, Microchem. J., 132 (2017) 238-244.

42. M. Moussa, V. Pichon, C. Mariet, T. Vercouter, N. Delaunay, Potential of ion imprinted polymers synthesized by trapping approach for selective solid phase extraction of Ianthanides, Talanta, 161 (2016) 459-468. 
43. M. Fayazi, M. Ghanei-Motlagh, M.A. Taher, R. GhaneiMotlagh, M.R. Salavati, Synthesis and application of a novel nanostructured ion-imprinted polymer for the preconcentration and determination of thallium(I) ions in water samples, J. Haz. Mat., 309 (2016) 27-36.

44. B. Gao, J. Meng, Y. Xu, Y. Zhang, Preparation of Fe(III) ion surface-imprinted material for removing $\mathrm{Fe}(\mathrm{III})$ impurity from lanthanide ion solutions, J. Ind. Eng. Chemi., 24 (2015) 351-358.

45. M. Andaç, R. Say, A. Denizli, Molecular recognition based cadmium removal from human plasma, J. Chrom. B, 811 (2004) 119-126.

46. N. Candan, N. Tüzmen, M. Andaç, C.A. Andaç, R. Say, A. Denizli, Cadmium removal out of human plasma using ion-imprinted beads in a magnetic column, Mat. Sci. and Eng. C, 29 (2009) 144-152.

47. A. Ersöz, R. Say, A. Denizli, Ni(II) ion-imprinted solidphase extraction and preconcentration in aqueous solutions by packed-bed columns, Anal. Chim. Acta, 502 (2004) 91-97.

48. R. Keçili, R. Say, A. Ersöz, H. Yavuz, A. Denizli, Purification of penicillin acylase through a monolith column containing methacryloyl antipyrine, Sep. Pur. Tech., 55 (2007) 1-7.
49. Z. Baysal, E. Aksoy, i. Dolak, A. Ersöz, R. Say, Adsorption Behaviours of lysozyme onto polyhydroxyethyl methacrylate cryogels containing methacryloyl antipyrine-Ce(III), Int. J. Poly. Mat. Poly. Biomat., 67 (2018) 199-204.

50. E. Birlik, S. Büyüktiryaki, A. Ersöz, A. Denizli, R. Say, Selective separation of thorium using ion imprinted chitosan phthalate particles via solid phase extraction, Sep. Sci. Tech., 41 (2006) 3109-3121.

51. H. Lianga, Qi. Chen, J. Mab, Y. Huang, X. Shen, Synthesis and characterization of a new ion-imprinted polymer for the selective separation of thorium(IV) ions at high acidity, Royal Soc. of Chem., 7 (2017) 35394-35402.

52. I. Yener, E. Varhan Oral, I. Dolak, S. Ozdemir, R Ziyadanogullari, A new method for preconcentration of $\mathrm{Th}(\mathrm{IV})$ and $\mathrm{Ce}(\mathrm{III})$ by thermophilic Anoxybacillus flavithermus immobilized on Amberlite XAD-16 resin as a novel biosorbent, Eco. Eng., 103 (2017) 43-49. 